\title{
AN INVESTIGATION INTO IRISH HISTORICAL CERAMICS: THE BRICK OF ARCH HALL, WILKINSTOWN, CO. MEATH
}

\author{
By SARA PAVÍA* \\ Department of Civil, Structural and Environmental Engineering, \\ Trinity College Dublin \\ and \\ SUSAN ROUNDTREE \\ City Architect's Division, Dublin City Council
}

[Received 4 July 2004. Read 14 February 2005. Published 00 xxxx 2005.]

\begin{abstract}
A letter written in 1710 by Robert, first Viscount Molesworth, to his wife describes ongoing work to the garden of their estate in Co. Dublin and to the digging of ponds and the subsequent making of bricks. This connection between the formation of designed landscape and the production of brick for building purposes has prompted the following scientific investigation. The paper applies physical science to the study of eighteenth-century Irish brick in order to gather information about its provenance and the source of its constituent materials. Analytical techniques were employed to study the bricks used to build Arch Hall, a mansion house dating from the first half of the eighteenth century with an extensive demesne in Co. Meath. Clay samples were collected from the demesne, fired in the laboratory and analysed for comparative purposes. The results indicate that the bricks are hand-made with silica-based, predominantly non-calcareous clay of glacio-fluvial origin. Firing temperatures ranging between $700^{\circ} \mathrm{C}$ and $1000^{\circ} \mathrm{C}$ were deduced based on mineralogical and colour changes during firing. The colour of both the original brick and the fired samples is consistently orange-red. This is due to the presence of dispersed hematite formed during firing in an oxidising atmosphere from the iron-bearing minerals in the clay. The petrography of the pointing mortar was used as an additional resource to gather evidence for provenance. The brick temper and mortar aggregate are consistent with each other and with the geology of the area, suggesting a local source for both the brick-making sediment and the mortar aggregate.
\end{abstract}

\section{Introduction}

Seventeenth-century documentary sources, such as Pynnar's survey (1618-19), mention the preparation and assembly of building materials on site for specific building projects. Brick-making on or adjacent to building sites is recorded in several parts of Ireland throughout the seventeenth and eighteenth centuries. In the precinct of Mountjoy in Co. Tyrone, for example, Lord Uchelrie, a Scottish landowner of 3,000 acres arrived in Ireland with thirty-three followers. In 1611 he is described as having sundry men at work preparing materials for building a cas-

* Author's e-mail: pavias@tcd.ie

Proceedings of the Royal Irish Academy, Vol. 105C, No. 6, 221-242 (2005) @ Royal Irish Academy 
tle. The work included felling 240 trees, and preparing stone, brick and lime for the building (Hill 1877).

It seems likely that bricks were produced locally whether for major or minor purposes in the building of large houses in rural areas. Building accounts, in several instances, indicate that bricks were specifically made on site for each project. This practice is noted in connection with the building of a pigeon house at Lismore in 1626 (Boyle/Lismore Papers, Irish Architectural Archive, transcripts by Moore and Crookshank, vol. 2, p193), the building of the mansion house at Burton in Co. Cork in 1665 (HMC, Egmont MSS, 1909, vol. 2) and at Lisburn in 1667. Sir George Rawdon, writing to Lord Conway about the construction of a pigeon house there in 1677 , notes that it will not be possible to build that year because 'bricks must be burnt first there' (CSPI 1666-9, 30 April 1667, 354). Within the seventeenth-century demesne of Portumna Castle, the recent discovery of the remains of a postmedieval brick kiln made with brick consistent with the seventeenth-century brick in the castle supports the foregoing documentary evidence of local manufacture (Bennett 1998). Studies to determine the provenance and technology of the Portumna brick with mineralogical and petrographic methods also suggest that the brick was locally made (Pavía et al. 2000).

In the early eighteenth century, the materials used for building Carton House in Co. Kildare are described as including home-made bricks. Local brick production is also noted in relation to the building of Bellamont Forest in Co. Cavan, Ireland's first Palladian villa, designed by Edward Lovett Pearce and completed in 1729 (The Georgian Society Records, 1913 (reprinted 1969), vol. V, 40). The practice of using locally-produced materials, including brick, seems reasonable given the difficulties of transporting building materials, particularly in inland areas, before there were proper roads or canals. Thus, the use of brick in country-house construction during this time provides important evidence that the expertise and material to make bricks locally appears to have been available in many parts of Ireland from the seventeenth century onwards.

The practice of brick-making in Ireland, however, has never been the subject of scientific analysis. With this purpose in mind, the authors set out to examine an early-eighteenth-century mansion house on an abandoned demesne in Co. Meath. Arch Hall is a brick-built house in ruins, its landscaped setting largely lost to the natural order. The demesne is located in a remote area, not close to any waterway or significant transport route. In its ruined state, it presents an excellent opportunity for analysis of its construction materials.

\section{Description of Arch Hall Demesne}

The standing structure that remains at Arch Hall is the fragmentary shell of a large, early-Georgian house (Pl. I). All that survives is a three-storey, nine-bay entrance front with cylindrical turret-like bows at each end and a broader three-bay semicircular bow at the centre of the façade. Arch Hall is one of a small group of Irish buildings in Vanbrugh's castle style making use of bows and circular rooms at an early date. For this reason it is suggested that the design may be attributed to Sir Edward Lovett Pearce (Craig 1996). Pearce, acknowledged to be the most influential architect in Ireland in the early part of the eighteenth century, also contributed both architecturally and legislatively to the development of the use of brick in Ireland. His building act, passed in 1730, was an attempt both to improve building construction 


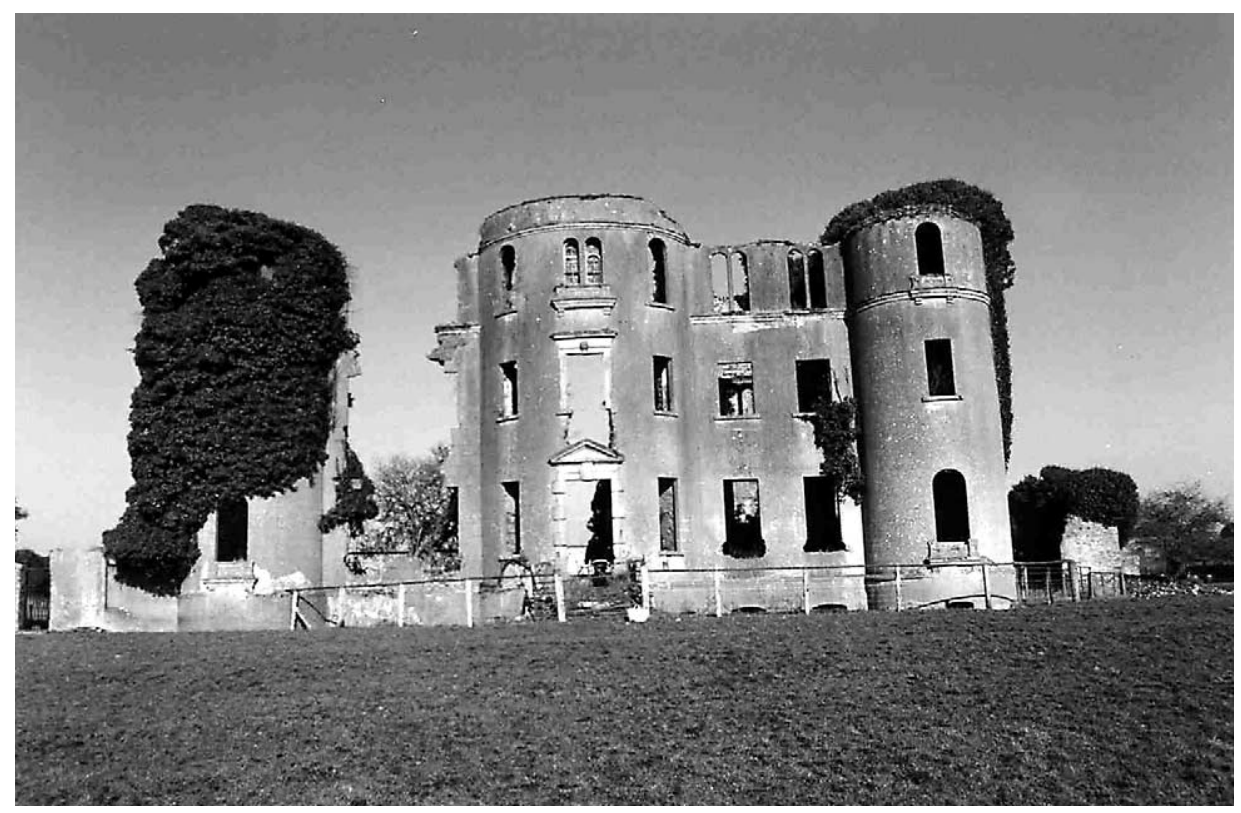

PL. I - The standing structure that survives at Arch Hall is the fragmentary shell of a large early Georgian house.

standards and to promote good brick-making practice in Ireland. These standards influenced and enhanced the work of his assistant and successor Richard Castle, and the work of subsequent Irish architects throughout the eighteenth century.

Behind the surviving façade Arch Hall is only one room deep and is built over a brick, vaulted basement. The hall, originally a large space with curved ends, was flanked by a reception room on each side. The room to the right of the hall retains its original dimensions and is roughly eighteen feet square. Throughout the ruin, fragments of plaster panels cling to the brickwork and, in one of the circular towers, a shallow saucer dome is ornamented with plaster coffering and egg-and-dart mouldings. Remodelled in the nineteenth century, the front façade, formerly of brick, is now rendered and curious paired, Romanesque windows and Italianate sills were added to the attic storey. The main structural walls are of red brick with lime mortar joints. The bricks are of slightly varying size indicative of their hand-made status. They measure from 9 to $9 \frac{1}{2}$ inches long, $4 \frac{1}{4}$ to $4 \frac{1}{2}$ inches wide, and are generally $2 \frac{1}{2}$ inches deep.

An eye-catching arch flanked by obelisks designed in the Vanbrugh (therefore also Pearce) manner gives Arch Hall its name. The grand arch, in a field south of the house, is a large, folly-like, rubble archway with a rustic pinnacle and low, flanking wings, all in an eighteenth-century romantic idiom. Other garden follies include a tall, grotto-type, rubble bridge over a narrow canal to the east of the house crowned by a square, chimney-like construction, possibly a plinth for a monument (Howley 1993).

The first edition Ordnance Survey map (Co. Meath, sheet 18) published in 1837 provides information about the original landscape of the estate (see Fig. 1). Two 
bridges are shown over a narrow canal that is diverted from the Yellow River. Access to the demesne is via a tree-lined avenue from the Kells to Wilkinstown road, with a lodge at the entrance gates. The avenue branches west of the house and a service route to extensive outbuildings is indicated north of a walled garden also to the west of the house; the main avenue follows a curved route to the south of the walled garden. An extensive lake is shown to the south-west of the house. The landscaped setting of the house is depicted in several nineteenth-century images. A painting by J.W. Baldock dated 1854 shows the building owner of that time, Mrs Garnett, on horseback, with her sons; the house is depicted with steeply-pitched roofs and conical towers. A photograph of the house from a similar location, $c .1860$, presents a view of the house from across the lake (Pl. II).

Arch Hall, in the townland of Newtown-Clongill, is associated with both the Payne (also Paine) and Garnett (also Garnet) families. While the precise building date is not known, a 1714 deed (Registry of Deeds, Meath 1708-45, Book 20, 62) records a transfer of lands at Clongell (sic) from John Raphson to William Paine (510 acres). William had two sons, Lawrence and John. Anne Paine, daughter of Lawrence, married Benjamin Woodward of Drumbarrow in 1737. Her marriage settlement included the town and lands of Clongill and Newtown Clongill (Registry of Deeds, Meath 1708-45, Book 92, 257). From this information, and from stylistic provenance, it seems certain that the mansion house was constructed in the 1730s, and therefore could have been designed by either Pearce or Richard Castle.

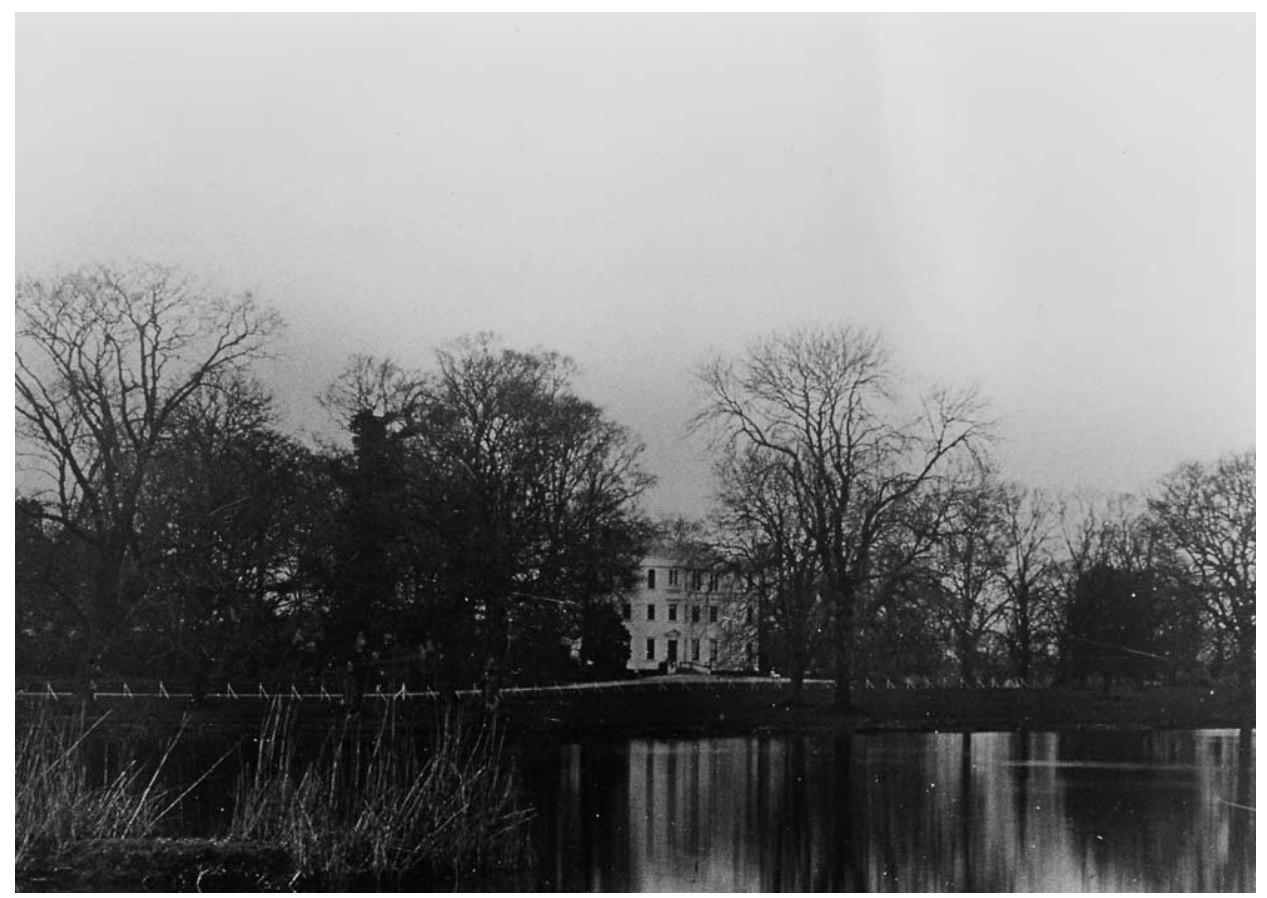

PL. II - Arch Hall, the Entrance Front $c .1860$. Courtesy of the Irish Architectural Archive. 


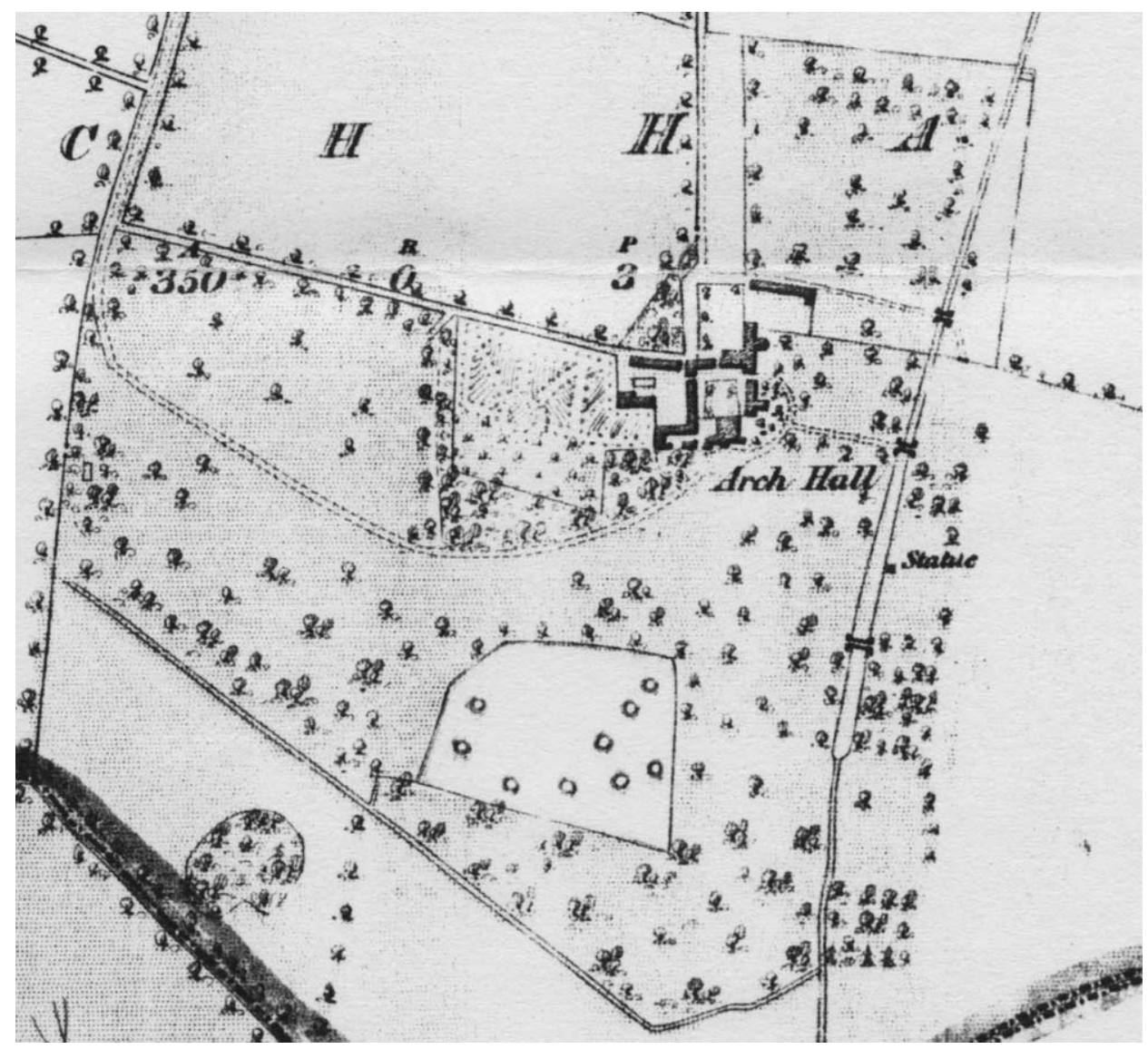

FIG 1 - First edition ordnance survey map (County Meath, sheet 18) published in 1837, providing information about the original landscape of the estate. Reproduced by permission of the Map Library, Trinity College Library, Dublin.

\section{Eighteenth-century estate brick-making}

There are no local brick-fields or brick-making locations indicated on the early Ordnance Survey map in the immediate or wider area of Arch Hall. However, there is some evidence of estate brick-making for specific purposes in Ireland from the seventeenth century onwards (Roundtree 1999). A number of estates had their own brick fields or regular places where bricks were made intermittently, as required for estate-building purposes and repairs. References to brick-making in this manner exist in family papers, as previously mentioned, for example, on the Molesworth estate at Brackenstown (National Library of Ireland, Molesworth Papers, n.4081, 3752, on microfilm). Evidence of these brick-making sites appears on later maps long after the practice ceased: for example, 'Brickfield', noted on an 1844 map of Ardgillen Estate, Co. Dublin, by George Conroy (The National Archives, Taylor Papers, M7069), and 'Brickfield Grove', noted at Birr Castle Demesne on a twentieth-century Ordnance Survey map (Co. Offaly, Sheets XXXV.9/10, surveyed 1909-10). 
From this documentary evidence it seems likely that the bricks used to build Arch Hall were made locally, on or adjacent to the estate. There is also a possibility that material excavated to carry out landscaping works, i.e. the formation of the lake and the canals, may have been used for brick-making purposes. As noted previously, this practice is referred to at Brackenstown and described in the Molesworth papers. For this reason, the soil samples examined were taken from several locations adjacent to the house, from the former lake area and from the edge of the surviving canal.

\section{Objective}

The ultimate objective of this study is to present information about the bricks at Arch Hall: their technology, provenance, sources of raw materials and trade or exchange patterns. To this end, scientific methods as well as analytical techniques of physical science focused on both the historic brick and the local clay samples.

\section{Methodology}

Analytical techniques including petrographic microscopy, X-Ray Diffractometry (XRD) and Scanning Electron Microscopy (SEM) with an Energy Dispersive X-Ray Diffraction attachment (EDX) were used to study the Arch Hall brick and the local fired clay. Conventional fieldwork involving standard inspections and recording was followed by sampling. The external features of the brick were studied by visual examination. Representative samples of brick were randomly taken from the original eighteenth-century part of the building. Clay samples from two areas adjacent to the house were gathered for analysis. The local clay was kneaded and fired in the laboratory. Clay balls were made and dried in laboratory conditions for twenty-four hours and later in a Memmert oven, also for twenty-four hours, at $100^{\circ} \mathrm{C}$. The clay was then fired in a Lenton furnace at temperatures of $700^{\circ}, 800^{\circ}, 900^{\circ}$ and $1000^{\circ} \mathrm{C}$. On each firing process, the temperature was increased in intervals to reach the aforementioned top firing temperatures.

The mineralogy of the original brick and the local fired clay was analysed by Xray diffraction (the powder method) with a diffractometer Philips PW 1710 using $\mathrm{Cu} \mathrm{K} \alpha$ radiation with a voltage of $40 \mathrm{kV}$ and an intensity of $40 \mathrm{~mA}$. The area was scanned between 2 and 60 degrees $2 \theta$. This analytical technique allows identification of the mineral phases present in the bricks and the presence or absence of diagnostic minerals. These are new crystalline phases formed during firing that provide a basis to establish the firing temperature. XRD allows the identification of mineral phases of low crystallinity that could not be determined with the lower resolution of the petrographic microscope. Finally, in order to gather data on the provenance of the brick, the mineralogy of the fired clay was compared with the mineral assemblage in the brick.

Petrographic microscopy was used to analyse the brick matrix and temper (phases with a diameter greater than $15 \mu \mathrm{m}$ (Maggetti 1982)). Thin sections of brick were polished to the standard thickness of $20 \mu \mathrm{m}$, covered with a glass slip and examined with a petrographic microscope. The samples were dyed with a chemical solution containing alizerine and potassium ferrocyanide. This made it possible to distinguish, under the microscope, different carbonate minerals. In order to preserve the original features of the bricks, the samples were impregnated in a deepblue-coloured resin under vacuum before thin-sectioning. Petrographic examination was carried out using polarised transmitted light and crossed polars. 
Petrographic analysis of the brick temper was undertaken to identify local or foreign production: this is an especially effective method for examining coarsegrained ceramics (Maggetti 1982). This technique was also used in the analysis of pores, cements and birefringence of brick matrices in order to quantify sintering and vitrification. Thin sections of pointing mortar taken from the brick masonry of Arch Hall were also analysed with a petrographic microscope in a similar manner. A detailed petrographic study of a mortar provides information on the type, origin and proportions of the raw materials used for its fabrication. The study focused on the mineralogy and petrology of the mortar aggregate, later to be compared to those of the brick temper in order to provide further evidence on provenance.

The bricks were also examined with a scanning electron microscope (Tite and Maniatis 1975; Maniatis and Tite 1981). The analytical system employed was a Zeiss DSM-950 scanning electron microscope equipped with a backscattered electron detector and a LINK-QX 2000 energy-dispersive, X-ray-analysis attachment (EDX). Spectra were taken with a voltage of $20 \mathrm{Kv}$. through a beryllium window. This system was used to analyse the elemental composition of certain areas and to estimate the degree of vitrification of the matrix. The SEM provides information on firing temperatures based on the existence of glass phase that increases with the firing temperature and the duration of the firing (Tite et al. 1982, Freestone and Middleton 1991). Qualitative elemental analyses of specific crystals were obtained with the EDX attachment.

\section{Results}

\section{Visual examination}

The Arch Hall bricks display some of the most typical features of the hand-made range. They are variable in size, texture and colour and occasionally include grass or hay imprints, uneven surfaces and moulding striae (Firman and Firman 1967). There are slight variations in texture: some contain a sandier matrix with no coarse temper whereas others consist of a fine-grained matrix with scarce coarse temper and lamination. The temper includes coarse and very coarse sand, and occasional pebbles sized between 1 and $15 \mathrm{~mm}$. The colour of the brick ranges from an orange-red to a dark red and a red-brownish colour. The predominant colour is orange. Defects associated with firing such as reduction marks, scumming or black core are not common. In the interior of the building the bricks at ground level have lost material and show occasional efflorescence. The cause of this has not been investigated though the lack of an adequate damp course associated with fire damage and the brick porosity are likely to have been contributory factors.

\section{X-Ray Diffraction}

Table 1 includes the minerals present in bricks and the local fired clay analysed by $\mathrm{XRD}$. According to the results, quartz is a major constituent of both the brick and the fired clay. This result was expected because quartz is a major constituent of all brick clays and brick earths. Feldpars are also present in significant amounts in all samples analysed. Further experiments are needed in order to determine the exact phyllosilicate and clay mineral assemblage in the brick and the fired clay. However, approximately $30 \%$ of the bricks analysed (e.g. see Table 1, AH1 and AH2) probably contain chlorite and mixed layer clays, though the local clay fired under $800^{\circ} \mathrm{C}$ 
:<smiles>[Mg][AlH2]</smiles>

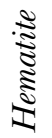

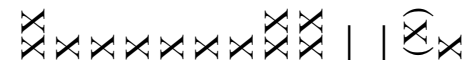

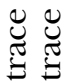

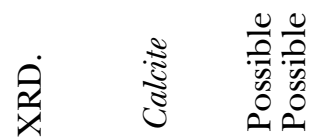

o.

อ

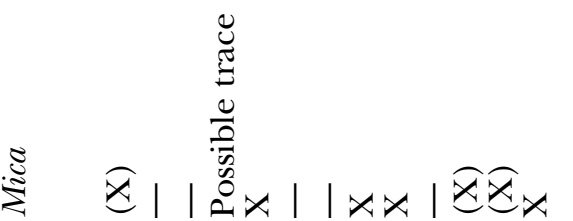

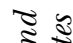

ह

$\frac{3}{2} \cdot \frac{\pi}{2}$

ฐ)

焉 $x x|| x x|| x x \widehat{x}$

ఏ

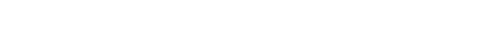

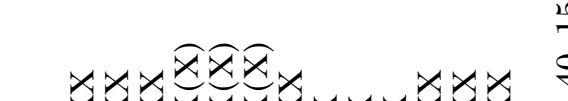

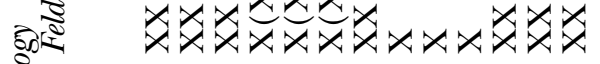

$x \times x \times x \times x \times x \times x \times x$

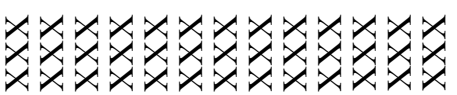

৩U৩๐

용ㅇㅇㅇ

$\pi \approx \pi \pi$

गृ

है

记过记

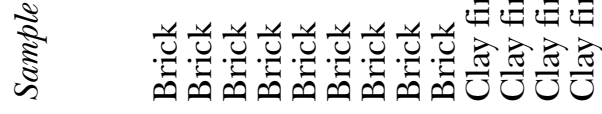

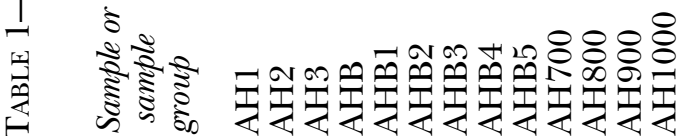


includes only traces of these minerals and minor amounts of other undetermined clays (probably including illite). On the other hand, the clay fired above $800^{\circ} \mathrm{C}$ contains less chlorite and mixed layer clays and no evidence of other clay minerals, but these samples do contain some mica.

Both the brick and the local clay are generally non-calcareous and therefore do not develop distinctive mineral associations during firing and thus lack diagnostic minerals. The clay fired at $1000^{\circ} \mathrm{C}$ is an exception, containing traces of calcium silicates (diopside-wollastonite). These diagnostic minerals formed from the calcium generated by the breakdown of calcite during firing. Calcite decomposes at approximately $600-850^{\circ} \mathrm{C}$ in fired natural clay, and the calcium silicates diopside-wollastonite appear in the range $850-900^{\circ} \mathrm{C}$ (Peters and Iberg 1978; Maggetti 1982). Minor amounts of calcite are present in two of the bricks studied. In contrast, calcite is not present in any of the samples of laboratory-fired clay. Hematite is present in all bricks and in $50 \%$ of the fired clay samples (those fired at higher temperatures). Hematite is one of the common iron oxides occurring in brick clays, mostly in red or reddish clays, and is the major colouring agent in red ware (Firman 1994).

\section{Firing experiments}

Initially, the firing temperature for the laboratory tests was to equal that deduced from the diagnostic minerals in the brick. However, due to the lack of diagnostic minerals and therefore the lack of specific information on firing temperatures, the brick was fired in a furnace at set intervals of $700^{\circ} \mathrm{C}, 800^{\circ} \mathrm{C}, 900^{\circ} \mathrm{C}$ and $1000^{\circ} \mathrm{C}$. The firing intervals chosen were based on previous studies (Pavía 1999a, 1999b; Pavía et al. 2000), where firing temperatures were deduced based on diagnostic minerals identified in clay bricks contemporary to the Arch Hall brick.

According to the results of firing, at $700^{\circ} \mathrm{C}$ and $800^{\circ} \mathrm{C}$ the clay is of a red-brownish colour whereas at $900^{\circ} \mathrm{C}$ and $1000^{\circ} \mathrm{C}$ it turns into a deep, orange-red colour. The brick colour is therefore temperature dependent: increasing the temperature darkens the colour and turns the clay a redder-orange shade.

\section{SEM analysis}

In order to estimate the firing temperature, the extent of vitrification of six representative brick samples was analysed with a SEM. Occasionally, a continuous glass phase typical of high temperature ceramics was visible under the SEM. Melting and welding had occurred locally, and the degree of particle interconnection was significant, suggesting an increase in firing temperature. However, in most of the fracture surfaces analysed, the bricks showed an open texture with loose particles, a flaky microstructure and a high intergranular porosity, features typically found in sedimentary materials (Pls III and IV).

EDX analyses of brick temper often showed solely silicon ( $\mathrm{Si}$ ), presumably indicative of quartz $\left(\mathrm{SiO}_{2}\right)$. Other cations detected in individual crystals analysed with EDX included $\mathrm{Si}$, aluminium $(\mathrm{Al})$, sodium $(\mathrm{Na})$ and potassium $(\mathrm{K})$. EDX analysis of the brick matrix showed elemental compositions mainly including $\mathrm{Si}, \mathrm{Al}$, iron (Fe) and alkalis. Elemental compositions of scanned areas of the brick matrix continuously showed the presence of Fe. Calcium (Ca) was only occasionally determined. The detection of anions including sulphur $(\mathrm{S})$ and chlorine $(\mathrm{Cl})$ together with $\mathrm{Ca}$ and alkalis suggests that anhydrite or gypsum and alkali chlorides were present due to weathering of some of the bricks (Pls V and VI). 

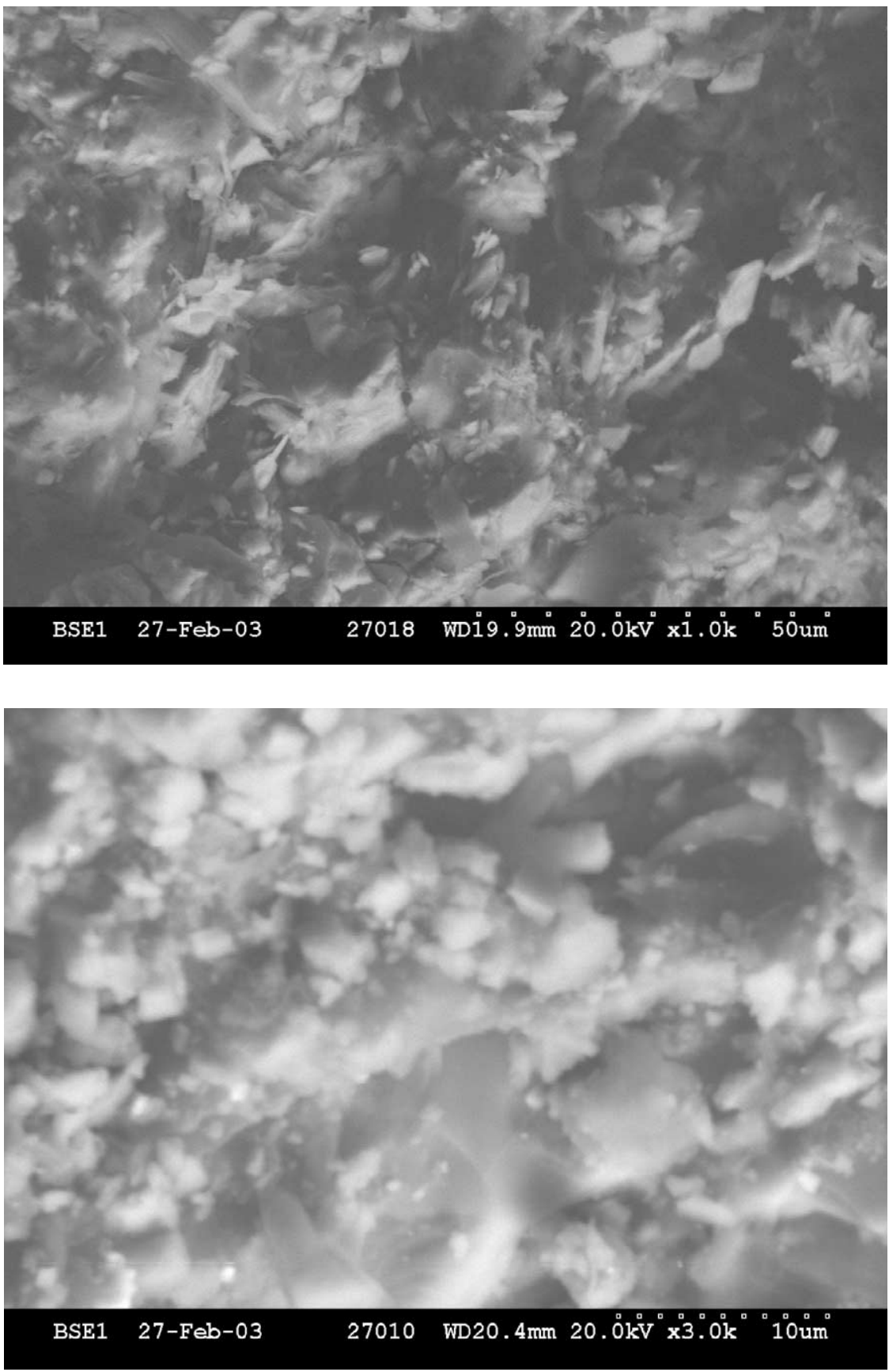

PL. III and IV — SEM images of Arch Hall brick: fracture surfaces showing local melting and welding and a predominant flaky microstructure with loose particles and a significant intergranular porosity. 


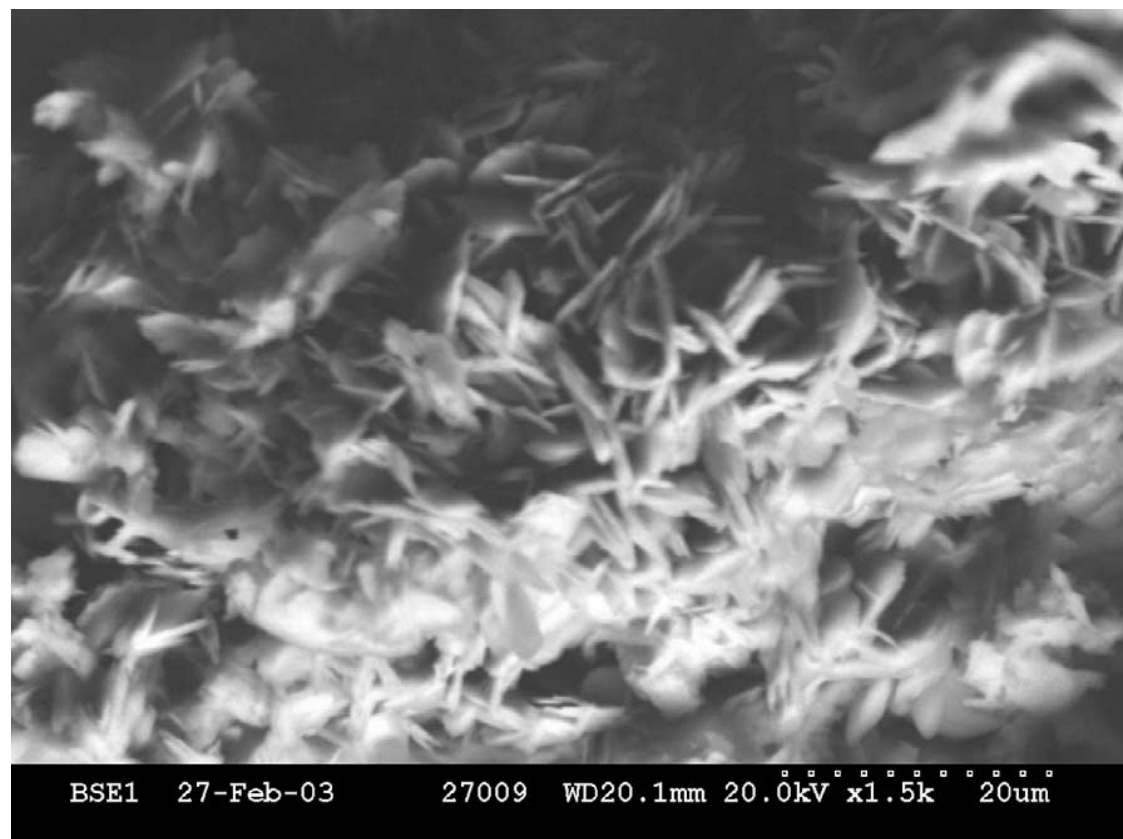

PL. V - SEM image of salt minerals on a brick surface (salts are analysed in the spectrum below).

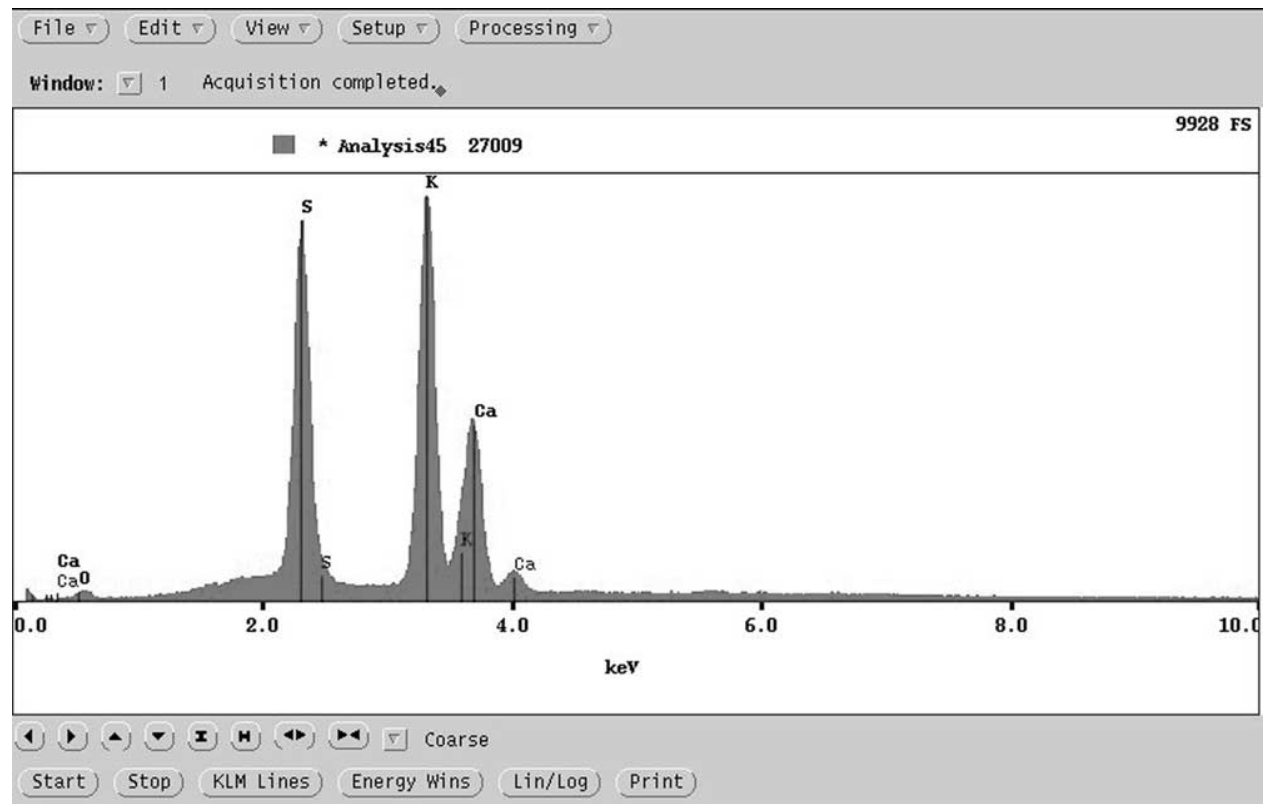

PL. VI — EDX analysis showing the presence of anhydrite or gypsum and alkali chlorides. 


\section{Petrographic microscopy}

The brick contains a high proportion of non-plastic material (Pls VII and VIII). Much of this material is sharp, sand-graded quartz, a thermally-resistant relict phase remnant of the raw sediment used for brick-making. Microscope analysis showed evidence of mineral transformation affecting chert (Pl. IX) and calcite (Pl. X) brick temper. Calcite in silicified limestone temper had decomposed leaving porous microcrystalline silica and secondary calcite as a remnant (Pl. X). Further transformation was recorded: reaction of peripheral microcrystalline silica with the adjacent matrix had formed rims in chert and sandstone temper displayed euhedral hematite and overgrown quartz. However, mineral transformation was restricted to reactive temper and, except for the euhedral hematite probably new-formed during firing, there was a general lack of crystals of firing phases with a well-developed crystalline habit.

Changes in the ceramic fabric due to firing were evident under the microscope. Some specimens (e.g. AHB1, see Tables 1 and 2) showed abundant sand-grade quartz with limited contacts with a birefringent matrix while in other bricks (e.g. AHB4, see Tables 1 and 2) the temper showed mineral transformation and the ceramic body had begun sintering and vitrifying, the degree of interconnection between particles had increased and the porosity had decreased. According to the petrographic microscope results, the bricks analysed fell into either of the two groups in Table 2. However, often, a single brick included features of both groups.

The main petrographic features of group AHB1 include the presence of individual particles with limited contacts, a birefringent matrix and a high porosity, typical of low temperature ceramics, whereas a significant degree of interconnection between particles, an opaque matrix, the occurrence of mineral transformations and overgrowths and a lower porosity (features of group AHB4) indicate higher temperatures.

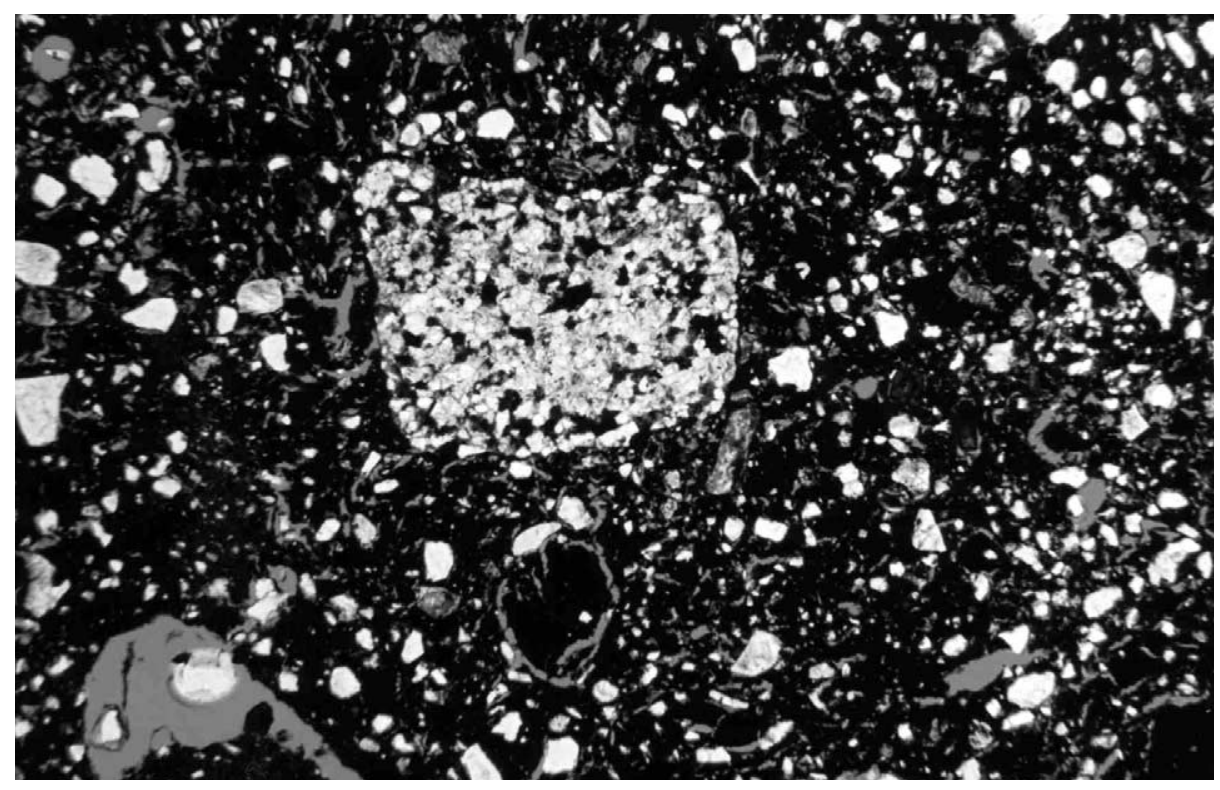

PL. VII - Petrographic microscope image of Arch Hall brick displaying sandstone temper. X2 parallel polarized light. 


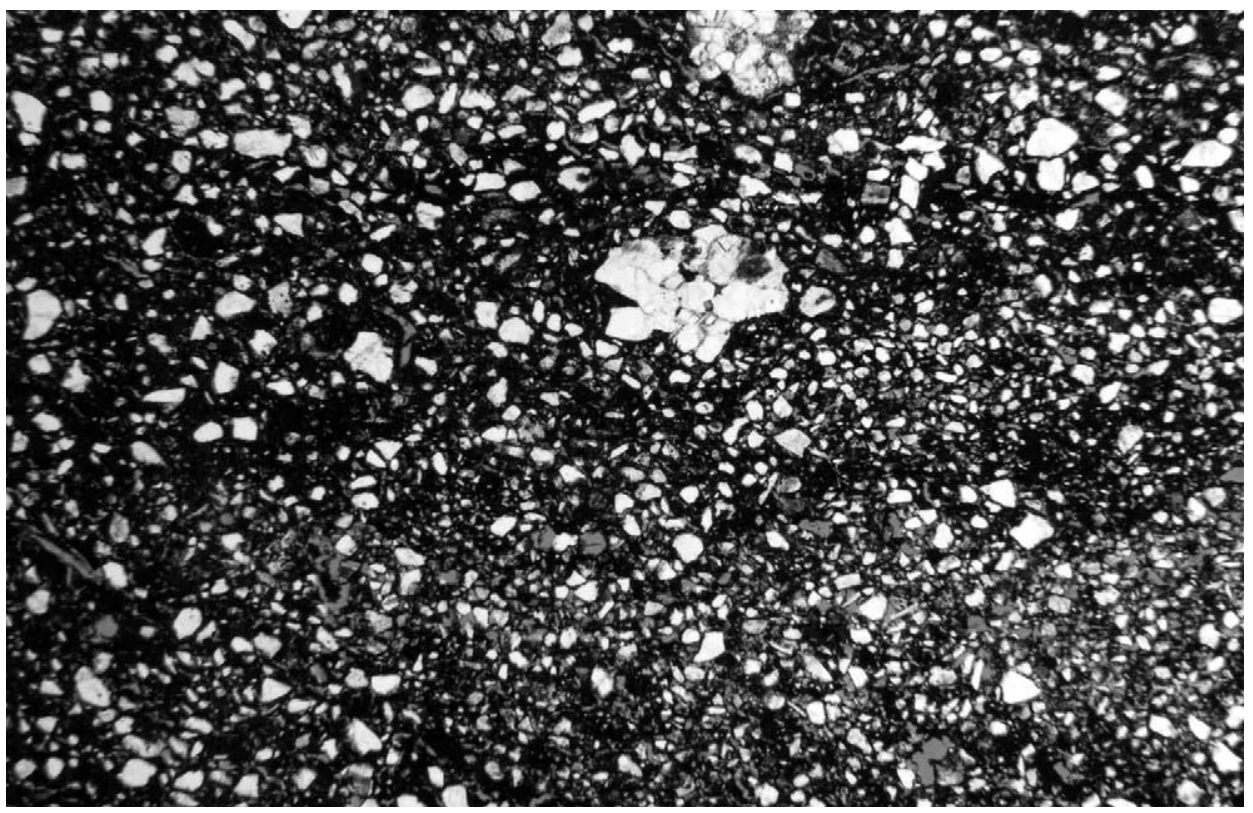

PL. VIII - The brick contains a high proportion of non-plastic material, mainly sharp, sand-graded quartz. X2 parallel polarized light.

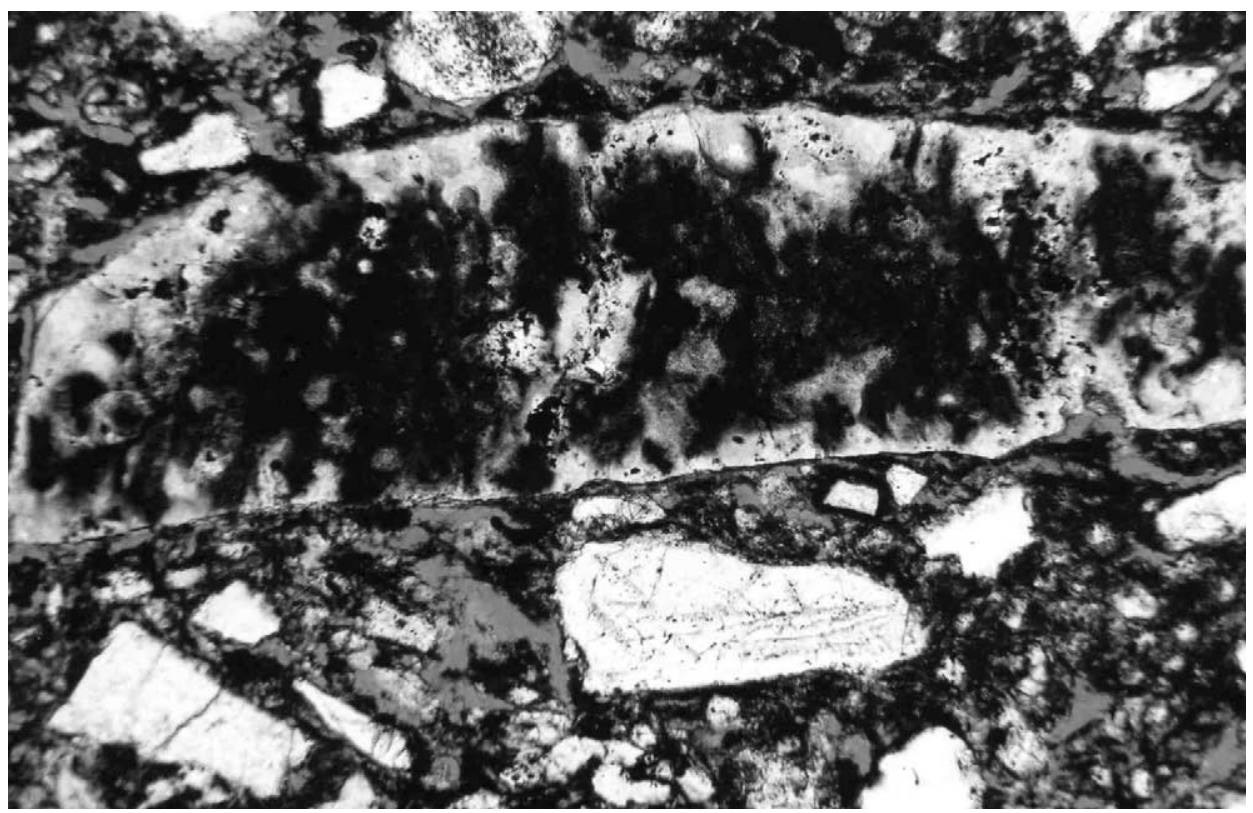

PL. IX — Microscope image of transformed chert temper. X10 parallel polarized light. 


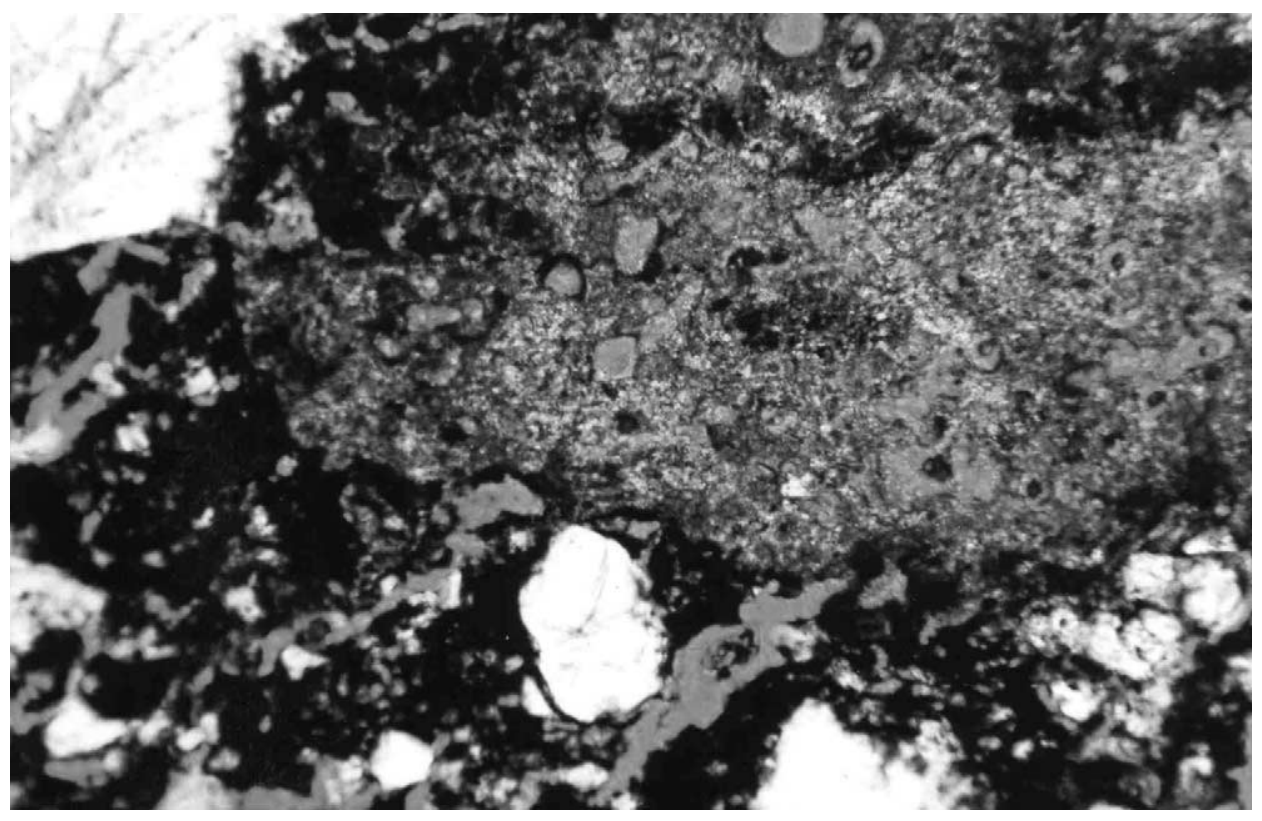

PL. X - Microscope image of the remains of a transformed limestone temper. X10 parallel polarized light.

TABLE 2-Petrography of the Arch Hall brick.

\section{Sample Temper \\ group}

AHB1 - Sharp, sand-grade quartz.

- Occasional feldspar and mica.

- Sandstone and shale.

AHB4 - Sharp, sand-grade quartz.

- Occasional feldspar and mica.

- Chert, sandstone and possible fragments of granite and metamorphic rocks.

- Silicified limestone partially vitrified.

- Transformed chert with pores and moulds of rhombohedral phases (originally probably a silicified limestone).

- Transformed temper including euhedral hematite and overgrown quartz.
Matrix

- Locally birefringent.

- Occasional contacts with temper.

- Approximate porosity of field of view $20-30 \%$ by volume.

- Opaque.

- Abundant contacts with temper.

- Occassional secondary calcite recrystallized both in matrix and in porous, partially transformed chert temper.

- Approximate porosity of field of view $15-20 \%$ by volume. 
Thin-section petrography occasionally indicated the presence of secondary calcite recrystallised in porous, partially-transformed chert temper. This technique also revealed a bimodal temper grading consisting mainly of sand-grade quartz and pebble-sized chert and rock fragments.

In order to gather further evidence of brick provenance the petrography of the mortar aggregate was compared to that of the brick temper. Table 3 includes the results of the petrographic analysis of the pointing mortar.

TABLE 3-Petrography of the lime mortar pointing the brick.

Aggregate

- Rounded quartz and rock fragments including limestone, chert, sandstone, shale and dolomite.

- Limestone can be dolomitic and/or silicified.

- Common sandstone with a clay matrix and a ferruginous cement.

- Occasional mica and fragments of granite.

According to the results presented in Table 3, the petrography of the Arch Hall brick displays similarities with that of its pointing mortar: for example, distinctive sandstone and chert are present both as aggregate in the mortar and as temper in the brick (Pls XI and XII). Furthermore, some of the brick temper that appears

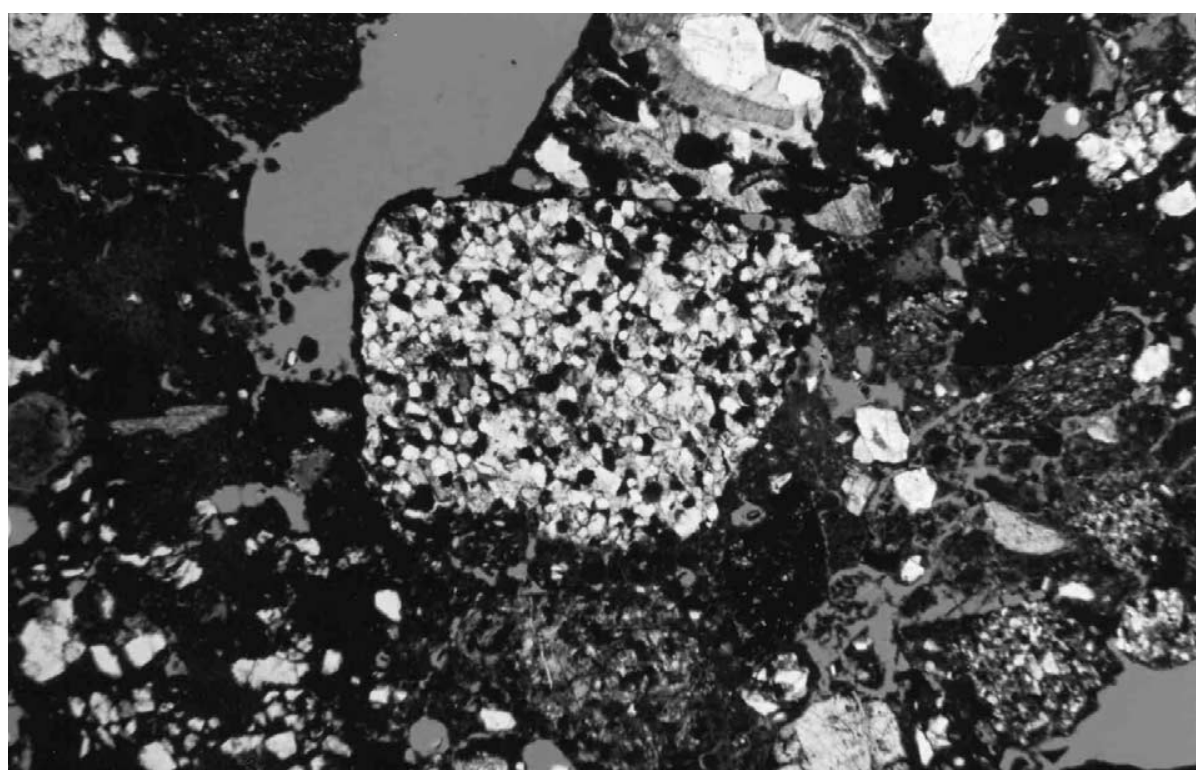

PL. XI - Petrographic microscope image of pointing mortar showing sandstone aggregate (centre) similar to the sandstone brick temper. X2 parallel polarized light.
Binder

- Porous, carbonated lime. 


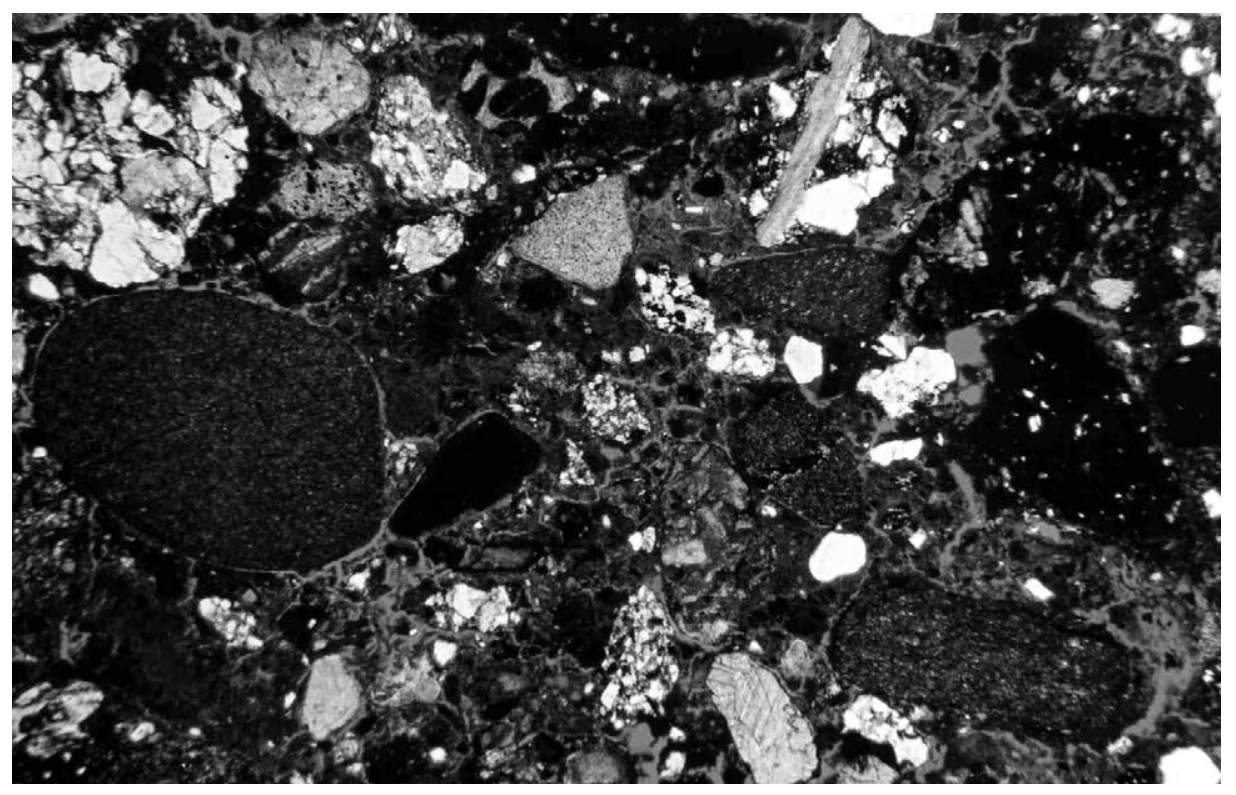

PL. XII - Microscope image of pointing mortar including aggregate of quartz and fragments of limestone, chert, sandstone and shale in a fractured, carbonated lime binder. X2 parallel polarized light.

now transformed as a result of firing was originally similar to certain mortar aggregate, including sandstone (Pl. XI) and silicified limestone (Pl. XII). The brick temper featuring transformed clay minerals with euhedral hematite and overgrown quartz would have originally matched the sandstone mortar aggregate with a clay matrix and a non-crystalline ferruginous cement. On the other hand, the transformed, porous, chert temper in the brick would have originally matched the silicified limestone aggregate in the mortar.

\section{Discussion}

\section{Brick Technology}

Shaping process. The bricks of Arch Hall display some of the most typical features of the hand-made range, including grass and/or hay imprints, uneven surfaces and moulding striae. They were probably hand-made using moulds. On the basis of this information and the knowledge of the contemporary brick-making process, it is probable that they were hand-made using wooden moulds.

Additions. Petrographic examination suggests that part of the temper could have been artificially added. Thin-section petrography revealed an approximately bimodal temper grading consisting mainly of sand-grade quartz and pebble-sized chert and rock fragments. According to Maggetti (1995), one out of four arguments used for identification of artificially-added temper is a bimodal size distribution. However, this on its own is a weak argument and the possibility of temper being artificially added should be further investigated. 
Type of raw material. The brick was made with a silica-based, predominantly non-calcareous, raw clay with a high percentage of non-plastic material that did not produce diagnostic minerals when fired. It is not possible to determine a specific range of firing temperatures because of this lack of diagnostic minerals.

The mineralogy of the brick, as well as the petrography of its temper, suggest that the raw clay for brick-making was probably gathered from a glacial or glaciofluvial deposit. The bricks include a high percentage of non-plastic material (sharp sand-grade quartz), a significant hematite content and the presence of chert and transformed limestone and other rock fragments. These features are similar to those of bricks made with glacial clay in the Dublin area, e.g. Rathfarham Castle (see Pavía 1999a and 1999b), that are contemporary to the Arch Hall brick. The glacio-fluvial origin hypothesis also corresponds with the conclusions of previous studies of glacial sediments in Dublin by Farrell et al. (1995). These studies revealed a mineralogical composition consistent with the underlying geology, including chlorite, illite, quartz and calcite and a clast composition of Carboniferous limestone $(80-90 \%)$ and sandstone $(7-13 \%)$.

Elemental compositions of single crystals and brick matrix determined with EDX support the results of petrographic analysis. These show that most of the brick temper is quartz $\left(\mathrm{SiO}_{2}\right)$. Fragments of argillaceous sandstone and other rocks were also recorded with SEM/EDX and petrography. The continuous presence of Fe in the matrix recorded with EDX corresponds with XRD results showing that hematite $\left(\mathrm{Fe}_{2} \mathrm{O}_{3}\right)$ was present in all bricks.

Firing technique. The firing technique was probably kiln firing. The continuous presence of hematite as well as the red and orange colours of most brick indicate that the brick was fired in a permanently oxidising atmosphere, therefore suggesting a kiln operation. The type of firing atmosphere is related to the method of firing (kiln or bonfires), and is partially responsible for certain characteristics of the fired ware, e.g. colour. Reducing conditions are typical of clamps or open fires where the ware is in contact with the fuel and the atmosphere can be very variable, subject to variations in wind and weather. In contrast, brick displaying fully-oxidised bodies are typically kiln-fired, where fuel and ware are separate and oxidising conditions can be controlled during the firing process. The firing technique may also induce the appearance of typical defects related to the presence of carbon (C) and/or sulphur (S). The lack of defects related to clamp firing such as black core, reducing marks or scum found in previous studies (Pavía and Bolton 2000) would also suggest a kiln-firing operation.

Firing temperature. The brick was made with a silica-based, predominantly non-calcareous, raw clay, as noted above, that did not produce diagnostic minerals when fired. Due to this lack of diagnostic minerals, a range of specific firing temperatures has not been determined.

The variability of the material studied makes it difficult to estimate firing temperatures through SEM and petrographic microscopy. SEM and petrographic analyses produced variable results ranging from vitrified areas or areas showing mineral reaction to those that have undergone very little change through firing. In a single brick, non-vitrified areas with an open texture and loose particles alternate with those where transformation was evident and the ceramic body had begun sintering and vitrifying, suggesting an increase in firing temperature. The great variation in the degree of 
transformation determined by SEM and petrographic analysis is probably due to compositional variations rather than to a wide range of firing temperatures.

However, petrographic microscopy provided evidence that the primary calcite in the silicified limestone temper was decomposed as a result of heating. This calcite was partially transformed back into secondary calcite by carbonation in a later postfiring stage, producing a porous microsilica temper with associated micritic calcite (Pl. X). This indicates that the temperature reached was at least $850^{\circ} \mathrm{C}$ (calcite thermally decomposes in the interval $600-850^{\circ} \mathrm{C}$ in a heated, natural clay).

Assuming the brick was made with local clay, an approximation to the firing temperature can be obtained by contrasting the results of the firing experiments with those of visual examination. According to site examination, the brick ranges in colour from orange-red to dark red and red-brown and the predominant colour is orange. Firing experiments reveal that the clay fired at $700^{\circ} \mathrm{C}$ and $800^{\circ} \mathrm{C}$ is of a red-brownish colour whereas at $900^{\circ} \mathrm{C}$ and $1000^{\circ} \mathrm{C}$ it turns into a deep orange-red colour. Accordingly, the firing temperature could span between $700-1000^{\circ} \mathrm{C}$ or over. These temperatures would be considered high for pre-nineteenth-century ceramics and would be more consistent with a kiln operation than with clamp firing.

Brick provenance. The clay field samples are silica-based, calcium-poor materials containing significant hematite and an abundant non-plastic fraction (sharp, sandgrade quartz). This clay is similar to that used to make the Arch Hall brick. The mineralogical composition of the local fired clay is similar to that of the Arch Hall brick. The best mineralogical match-based on XRD results-is that of brick AH1 and the clay fired at $1000^{\circ} \mathrm{C}$ (Pls XIII and XIV). The fact that the local clay occasionally contains limestone temper is a further similarity with the Arch Hall brick where transformed silicified limestone temper was observed with the petrographic microscope. Unfortunately both the brick and the local clay are generally non-cal-

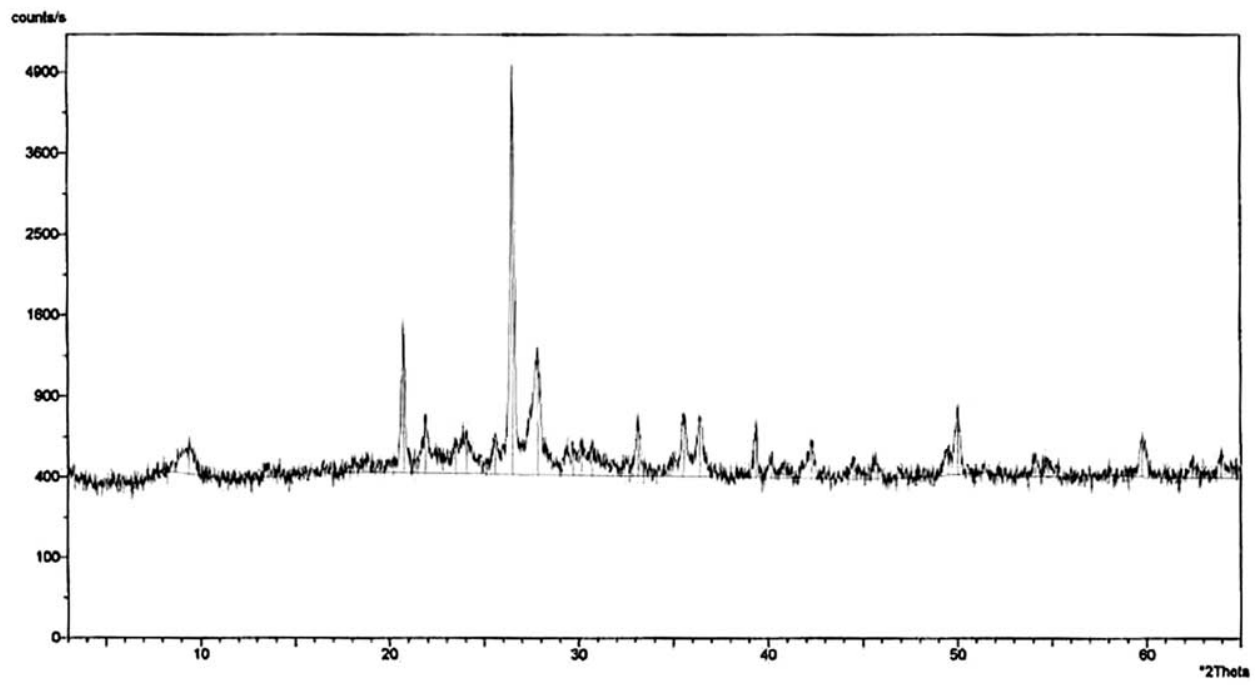

PL. XIII - XRD diagram showing the mineral composition of the clay fired at $1000^{\circ} \mathrm{C}$. 


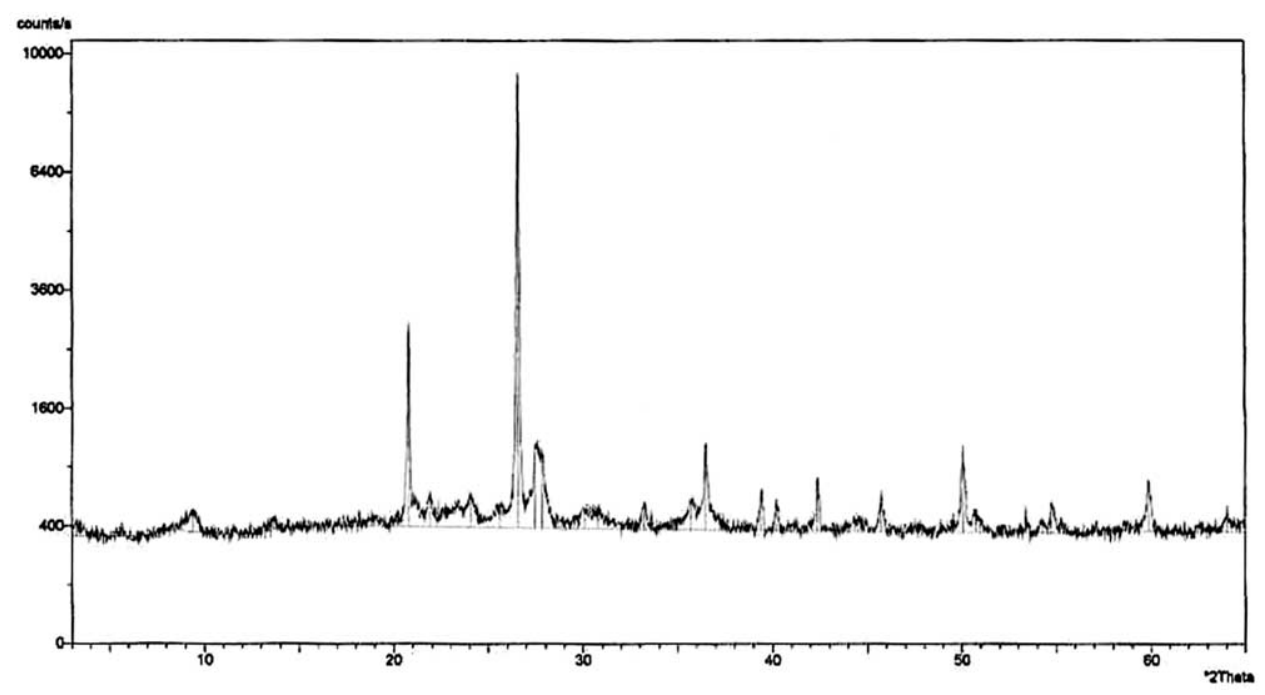

PL. XIV - XRD diagram showing the mineral composition of the Arch Hall brick.

careous and therefore do not develop distinctive mineral associations during firing that could be compared in order to reach a conclusive answer to the question of brick provenance.

According to the results from XRD and the firing experiments, the colour of the brick is similar to that of the laboratory-fired clay and is due to the presence of dispersed, fine-grained hematite that forms during firing in an oxidising atmosphere from iron-bearing minerals.

The most significant apparent difference between the mineralogical composition of the Arch Hall brick and that of the laboratory-fired clay is the presence of calcite in two bricks. However, it was demonstrated in this study that this is not a relevant difference because calcite is not a primary mineral inherited from the raw clay but a secondary mineral later formed in the brick as a consequence of weathering. Under the microscope, calcite appears forming sparitic crystals recrystallized in pores-features suggesting a secondary origin. This conclusion agrees with previous studies (Pavía 1994) where it was argued that calcite in clay brick was formed by dissolution of lime mortar binder and subsequent recrystallization within the porous brick.

Most of the mineral assemblages determined by XRD in both the brick and the fired clay are typical of the firing of non-calcareous clay. The clay fired at $1000^{\circ} \mathrm{C}$ is an apparent exception because it contains diopside-wollastonite-calcium silicates typically formed during firing of calcareous brick clays (Peters and Iberg 1978; Maggetti 1982). However, it was subsequently demonstrated by petrographic analysis that this sample is not an exception and that the presence of diopside and wollastonite is probably due to the transformation of limestone temper originally present in the raw clay.

The analysis of temper is consistent with a local source for the brick-making sediment. Petrographic analysis revealed the presence of quartz, chert, sandstone and other rock fragments as temper. These minerals, inherited from the raw clay, are con- 
sistent with the geology of the area. According to the Geological Survey of Ireland, the local geology is dominated by the Rathkenny and the Liscarton Formations, aged Ordovician-Silurian and Dinantian, respectively (Geraghty and McConnell 1999). The Rathkenny Formation includes black mudstone, siltstone and greywacke whereas the Dinantian materials consist predominantly of laminated and muddy limestones (McConnell et al. 2001). Arch Hall is adjacent to other bedrock areas including the Salterstown Formation to the North, consisting of greywacke and banded mudstone, and the Ballysteen Formation to the West, consisting of dark muddy limestone and shale (Geraghty and McConnell 1999; McConnell et al. 2001). The local limestone is often silicified and contains inter-bedded chert.

The aggregate in the lime mortar binding the brick is also consistent with the geology of the area. This paper has used the petrography of pointing mortar as an additional resource to gather evidence for ceramic provenance studies. In this case, the masonry mortars featured aggregate that was found as temper in the brick.

\section{Conclusion}

The bricks of Arch Hall were hand-made using moulds with a silica-based, predominantly non-calcareous, raw clay of glacio-fluvial origin probably excavated from an adjacent area, including significant hematite and a high percentage of non-plastic material. Both the brick and the local clay are generally non-calcareous and therefore do not develop distinctive mineral associations during firing that could be compared in order to conclude on provenance or to estimate a specific range of firing temperature. However, both the local clay and the brick occasionally contain silicified limestone temper.

The colour of the brick is similar to that of the local fired clay and is due to the presence of dispersed, fine-grained hematite formed during firing in an oxidising atmosphere, from iron-bearing minerals.

Firing temperatures of at least $850^{\circ} \mathrm{C}$ were deduced from the disappearance of calcite in brick temper. Temperatures from $700-1000^{\circ} \mathrm{C}$ were deduced by contrasting firing experiments with visual examination and on the assumption that the brick was made with local clay. The firing technique was probably kiln firing. The continuous presence of hematite as well as the red and orange colours together with the low frequency of defects related to clamp firing and the range of firing temperatures deduced suggest a kiln operation. The great variation in the degree of transformation of the brick determined by SEM and petrographic analysis is probably due to a significant compositional variation of the raw material rather than to a wide range of firing temperatures.

The analysis of temper suggests a local source for the brick-making sediment. The petrography of the pointing mortar was used as an additional resource to gather evidence for provenance studies. The mineral phases found both in the brick temper and the mortar aggregate are consistent with the geology of the area, suggesting a local origin not only for the brick but also for the mortar aggregate.

Petrographic and compositional features of the Arch Hall brick are consistent with those of other bricks made with glacial clay in the Dublin area. Bricks made with boulder clay are typically heterogeneous and contain a wide range of mineral phases from abundant inert quartz to reactive clay minerals and rock fragments such as limestone, sandstone or chert. 


\section{ACKNOWLEDGEMENT}

The authors would like to thank Dr Ron J. Firman, Department of Archaeology, University of Nottingham, Dr Patrick Wyse-Jackson, Department of Geology, Trinity College Dublin and Dr Edward McParland, Department of the History of Art, Trinity College Dublin for revising this paper. The authors would also like to thank the Irish Architectural Archive, the Registry of Deeds, and the National Library of Ireland for access to documentation; Mrs. Kitty Colwell, current owner of Arch Hall, for her welcome and for allowing access to the building; Dr R. Goodhue for helping with the XRD analysis; Ms Ana Reid, Faculty of the Built Environment, DIT, for her help firing the clay and Mr Neil Leddy, Mr Colin Reid and Mr David John of the Centre for Microscopy and Analysis, Trinity College Dublin, for assisting in the SEM analysis.

\section{ABBREVIATIONS}

CSPI Calenders of State Papers, Ireland, 1666-9.

\section{ARCHIVES}

Irish Architectural Archive, Boyle/Lismore Papers, 1626, vol. 2, p.193 (transcripts by Moore and Crookshank).

National Library of Ireland (NLI), Molesworth Papers, n.4081, p.3752 (on microfilm), letters from Robert Molesworth, afterwards 1st Viscount Molesworth, to his wife, 1689-1724.

Registry of Deeds, Meath 1708-45, Book 20, 62, Raphson to Paine.

Registry of Deeds, Meath 1708-45, Book 92, 257, Paine to Woodward.

\section{REFERENCES}

Bennett, I. (ed.) 1998 Excavations 1998: summary accounts of archaeological excavations in Ireland, no. 263. Bray. Wordwell.

Casey, C. and Rowan, A. 1993 The buildings of Ireland-North Leinster. London. Penguin.

Craig, M. 1996 The quest for Edward Lovett Pearce. Irish Arts Review 12, 29-34.

Farrell, E.R., Coxon, P., Doff, D.H. and Pried'homme, L. 1995 The genesis of the brown boulder clay of Dublin. Quarterly Journal of Engineering Geology 28, 143-52.

Firman, R.J. and Firman, P.E. 1967 A geological approach to the study of medieval bricks. Mercian Geologist 2 (3), 299-318.

Firman, R.J. 1994 The colour of brick in historic brickwork. British Brick Society Information 61, 3-9.

Freestone, I.C. and Middleton, A.P. 1991 Mineralogical applications of the analytical SEM in archaeology. Mineralogical Magazine 51, 21-31.

Georgian Society 1913 The Georgian Society records of eighteenth-century domestic architecture and decoration in Ireland. (Reprinted 1969) vols I-V. Dublin University Press.

Geraghty, M. and McConnell, B. 1999 Bedrock geology. 1:100,000 scale map series, sheet 13, Meath. Dublin. Geological Survey of Ireland.

Griffin, D., Robinson, N. and the Knight of Glin 1998 Vanishing country houses of Ireland. Dublin. Irish Architectural Archive and Irish Georgian Society.

Heimann, R.B. 1982 Firing technologies and their possible assessment by modern analytical methods. In J.S. Olin and A.D. Franklin (eds), Archaeological ceramics, 86-96. Washington, DC. Smithsonian Institution Press.

Hill, G. 1877 An historical account of the plantation in Ulster at the commencement of the seventeenth century. Belfast. M'Caw, Stevenson and Orr.

Historic Manuscripts Commission, 1909, Egmont MSS (British Library), vol. 2, (William Kenn to Sir John Perceval, 3 August 1665).

Howley, J. 1993 The follies and garden buildings of Ireland. New Haven and London. Yale University Press. Irish House of Commons Journals, vol. 1, 1613-61, 429. 
Maggetti, M. 1982 Phase analysis and its significance for technology and origin. In J.S. Olin and A.D. Franklin (eds), Archaeological ceramics, 121-33. Washington, DC. Smithsonian Institution Press.

Maggetti, M. 1994 Mineralogical and petrographical methods for the study of ancient pottery. In F. Burragato, O. Grubessi and L. Lazzarini (eds), First European workshop on archaeological ceramics, 10-12.10.1991, 25-35. Rome. Dipartimento Scienze della Terra, Università degli studi di Roma 'La Sapienza'.

Maggetti, M. 1995 Méthode chimique contre méthode minéralogique pétrographique dans l'étude des céramiques anciennes. In M. Vendrell-Saz, T. Pradell, J. Molera and Maite Garcia (eds), Estudis sobre ceràmica antiga / Studies on ancient ceramics: Proceedings of the European Meeting on Ancient Ceramics, 235-7. Barcelona. Generalitat de Catalunya, Departament de Cultura.

Maniatis, Y. and Tite, M.S. 1981 Technological examination of Neolithic-Bronze Age pottery from central and southeast Europe and from the near east. Journal of Archaeological Science 8, 59-76.

McConnell, B., Philcox, M. and Geraghty, M. 2001 Geology of Meath: a geological description to accompany the bedrock geology map series, sheet 13, Meath. Dublin. Geological Survey of Ireland.

Pavía, S. 1994 Material de construcción antiguo de Logroño y La Rioja Alta: petrografía, propiedades físicas, geología y alteración. Ciencias de la Tierra n ${ }^{\circ}$ 17. Logroño. Gobierno de La Rioja; Instituto de Estudios Riojanos.

Pavía, S. 1999a A comparative study of Mediaeval Irish clay brick. Presented at the Mineralogical Society of Great Britain and Ireland, Clay Minerals Group spring meeting, Trinity College Dublin.

Pavía, S. 1999b A study of seventeenth-century Irish clay brick. Presented at 'Mineralogy of Ceramics: ancient and modern', Mineralogical Society of Great Britain and Ireland, Applied Mineralogy Group meeting, London.

Pavía, S., Bolton, J., Walker, G., McMahon, P. and Dunphy, T. 2000 The brick in Portumna Castle, County Galway, Ireland. British Brick Society Bulletin 80, 5-10.

Pavía, S. and Bolton, J. 2000 Stone, brick and mortar. historical uses, decay and conservation of building materials in Ireland. Bray. Wordwell.

Peters, T. and Iberg, R. 1978 Mineralogical changes during firing of calcium-rich brick clays. Ceramic Bulletin 57 (5), 503-9.

Roundtree, S. 1999 A history of brick as a building material in Ireland. Unpublished MLitt thesis, Trinity College Dublin.

Tite, M.S. 1995 Firing temperature determinations-how and why? In A. Lindahl and O. Stilborg (eds), The aim of laboratory analyses of ceramic in archaeology, 37-42. Konferenser 34. Stockholm. KVHAA.

Tite, M.S. and Maniatis, Y. 1975 Examination of ancient pottery using the scanning electron microscope. Nature 257, 122-3.

Tite, M.S., Freestone, I.C., Meeks, N.D. and Bimson, M. 1982 The use of scanning electron microscopy in the technological examination of ancient ceramics. In J.S. Olin and A.D. Franklin (eds), Archaeological ceramics, 109-20. Washington, DC. Smithsonian Institution Press. 